\title{
Preparation and Canning of a Papaya Drink
}

\author{
A. J. Rodriguez and Lydia M. Iguina de George
}

\section{INTRODUCTION}

Increasing popularity of non-carbonated beverages among consumers is a new trend in the field of commercially-processed fruit drinks $(1,2,3,4){ }^{2}$ Such products are on the market under a variety of names as fruit drinks, juice drinks, breakfast drinks, ades, and others. In general, the fruit beverages consist of blends of fruit juices or pulps with water, sugar, and acid added. Coloring and flavoring material sometimes are added to enhance the final product.

The field of the fruit beverage is developing at such an accelerated pace that it lends itself to the establishment of product formulations totally based on artificial ingredients. It thus is not uncommon to find some containing little or no fruit among well-known brands that bear fruit-like names. These products could well be improved by the addition of one or more of the fresh fruits for flavoring purposes. This would provide an important market outlet for local fruit crops as well as enabling consumers to enjoy vitamin-enhanced, pleasant-tasting beverages with natural fruit flavors throughout the year.

In this report, a method for the preparation and canning of a papayabased beverage is described, data on its keeping quality is furnished, and results of consumer-acceptance tests are presented.

\section{MATERIALS AND METHODS}

Tree-ripened papayas from experimental plots in Isabela, Puerta Rico, were used for the formulation and canning of papaya beverages.

Fruits were carefully sorted, washed, and cut into halves to remove the seeds. Some of the lots were hand-peeled; others were processed without peeling. Fruit sections were cut further into smaller pieces to feed into the pulper. Papaya pulp extraction was performed in a Langsenkamp ${ }^{8}$ paddle pulper fitted with a 0.033 -inch screen. Immediately after the extraction, the extracted pulp was mixed with sucrose in a 1:1 proportion by weight,

1 Chemical Engineer and Assistant Food Technologist, respectively, Food Technology Laboratory, Agricultural Experiment Station, Mayagüez Campus, University of Puerto Rico, Río Piedras, P.R.

2 Italic numbers in parentheses refer to Literature Cited, p. 166.

8 Trade names are used in this publication solely for the purpose of providing specific information. Mention of a trade name does not constitute a guarantee or warranty of the equipment by the Agricultural Experiment Station of the University of Puerto Rico or an endorsement over other equipment not mentioned. 
and passed through a stonemill to reduce the size of the sweetened pulp particles to within the range of 0.004-0.006 inches. Water was added to dilute the pulp-sucrose mixture to 13-percent pulp content. Sliced West Indian lime was added in a proportion of 0.4 percent by weight of drink. The suspended lime portions were removed by straining the mixture through a 0.020-inch screen of a paddle finisher operated at low speed.

Sugar was added to the strained beverage to adjust the soluble solid concentration at $15^{\circ}$ Brix, while the $\mathrm{pH}$ was adjusted to 3.7 with citric or malic acid, food grade. The drink was flash-pasteurized at $185^{\circ}$ to $190^{\circ} \mathrm{F}$., packed in 8-ounce enameled cans, and stored at $85^{\circ} \mathrm{F}$.

Six lots of this papaya preparation were evaluated periodically through chemical analyses and sensory appraisals to determine the shelf life and keeping quality of the canned product stored at $85^{\circ} \mathrm{F}$. Refractometric solids, $\mathrm{pH}$, percentage total sugars, percentage reducing sugars, percentage pulp in suspension, and total titrable acidity were determined for the samples under study.

Refractometric solids-content readings, expressed as ${ }^{\circ} \mathrm{Brix}$, were obtained with an Abbe-type refractometer. The $\mathrm{pH}$ was determined by the A.O.A.C. glass electrode method (6), and total acidity was measured by potentiometric titration with $0.1 \mathrm{~N} \mathrm{NaOH}$ solution to $\mathrm{pH} 8.1$ using glass calomel electrodes. Total and reducing sugars were determined by the Lane and Eynon method (6). The pulp in suspension was determined by centrifuging a measured quantity of the beverage at 3,000 r.p.m. for 5 minutes.

For product evaluation, the samples were chilled and presented to a panel of trained tasters that scored the samples using a 9-point hedonic scale (7) and the method of Kramer and Ditman (5) in which +2, -2 or acceptablenot acceptable scale was used.

Acceptance tests to this type of papaya product were carried out in the continental United States, as well as locally.

\section{RESULTS AND DISCUSSION}

The chemical composition of the papaya beverage at the end of the 12-month storage period is given in table 1. Results do not show any appreciable difference in their composition when the samples prepared from peeled and unpeeled fruit were compared with each other. No significant change was observed during the year of study in any of the constituents measured that could be correlated with the overall quality of the beverage, with exception of the reducing sugars of sample No. 2. The rate of change of reducing sugars to total sugars is expressed in terms of a ratio $R=(\%$ reducing sugars) (100)/(\% total sugars), values of which are presented in table 2. It can be observed that there is a striking difference between the value of the ratio $(R)$ for sample No. 2 when compared with $R$ values for 
TABLE 1.-Results of the chemical analyses of papaya beverage samples under shelf-life study when fresh and afler a year of storage at $85^{\circ} \mathrm{F}$.

\begin{tabular}{|c|c|c|c|c|c|c|c|}
\hline Sample & $\mathbf{p H}$ & $\begin{array}{l}\text { Type of acid } \\
\text { added }\end{array}$ & - Brix & $\begin{array}{c}\text { Total } \\
\text { acidity }\end{array}$ & $\begin{array}{c}\text { Total } \\
\text { sugars }\end{array}$ & $\begin{array}{c}\text { Reducing } \\
\text { sugars }\end{array}$ & $\begin{array}{l}\text { Pulp in } \\
\text { suspension } \\
\text { 3,000 r.p.m. } \\
\text { per } 5 \\
\text { minutes }\end{array}$ \\
\hline \multicolumn{8}{|c|}{ Fresh } \\
\hline Number & & & & Percens & Percent & Pereent & Percent \\
\hline 1 & 3.59 & Citric & 14.6 & 0.13 & 14.40 & 2.36 & 26 \\
\hline 2 & 3.56 & do. & 14.9 & .12 & 14.86 & 13.70 & 26 \\
\hline 3 & 3.57 & do. & 15.0 & .13 & 14.84 & 2.77 & 24 \\
\hline $4^{1}$ & 3.63 & do. & 14.8 & .14 & 14.67 & 3.88 & 26 \\
\hline $5^{1}$ & 3.63 & do. & 14.7 & .14 & 14.32 & 3.75 & 26 \\
\hline 6 & 3.68 & Malic & 14.7 & .11 & 14.66 & 2.86 & 26 \\
\hline \multicolumn{8}{|c|}{ 12-months } \\
\hline 1 & 3.58 & Citric & 15.2 & 0.15 & 15.11 & 11.45 & 26 \\
\hline 2 & 3.54 & do. & 15.2 & .14 & 15.14 & 14.42 & 25 \\
\hline 3 & 3.58 & do. & 15.6 & .13 & 15.48 & 11.27 & 26 \\
\hline $4^{1}$ & 3.60 & do. & 15.2 & .15 & 15.22 & 11.72 & 24 \\
\hline $5^{1}$ & 3.72 & do. & 15.2 & .14 & 15.11 & 11.71 & 26 \\
\hline 6 & 3.65 & Malic & 15.1 & .13 & 15.05 & 10.38 & 24 \\
\hline
\end{tabular}

1 Samples prepared from unpeeled fruits.

TABLE 2.-Values of the reducing sugars: total sugars ratio during the storage period at $85^{\circ} F$.

\begin{tabular}{cccc}
\hline \multirow{2}{*}{ Sample } & \multicolumn{3}{c}{ Reducing sugars: total sugars ratio } \\
\cline { 2 - 4 } & Fresh & Storage period \\
\cline { 2 - 4 } & 16.3 & 5 months & 12 months \\
\hline 1 & 92.1 & 59.9 & 75.7 \\
2 & 27.5 & 98.8 & 95.2 \\
3 & 26.4 & 58.2 & 72.8 \\
4 & 26.2 & 64.7 & 77.0 \\
$5^{1}$ & 19.5 & 55.9 & 77.5 \\
6 & 51.1 & 68.7 \\
\hline
\end{tabular}

${ }^{1}$ Samples prepared from unpeeled fruits.

the other samples. This high value of sample No. 2 during the whole year of study coincides with the fact that it has been consistently the least acceptable of all the samples evaluated since the beginning of the study.

Before submitting the papaya samples for evaluation, the taste panel was trained with commercial preparations of grape, tamarind, apple, grape- 
fruit, and West Indian cherry to familiarize them with the taste, nature, and consistency of this type of beverage.

The results of the evaluation of the papaya beverage presented in table 3 show that they kept an excellent quality during a year of storage at $85^{\circ} \mathrm{F}$.

Data in table 3 also shows that high quality papaya beverages with good shelf-life can be prepared from unpeeled fruits. Samples Nos. 4 and 5, prepared from this type of pulp, were very well accepted throughout the 365 days of the shelf-life study. No difference in the rate of acceptance was detected when samples containing citric acid were compared with the sample standardized with food grade malic acid.

TABLE 3.-Results of sensory evalualion of papaya beverage samples during a year of storage at $85^{\circ} \mathrm{F}$.

\begin{tabular}{|c|c|c|c|c|c|c|}
\hline \multirow{3}{*}{ Sample } & \multicolumn{3}{|c|}{$\begin{array}{l}\text { Rating in "acceptable- } \\
\text { notacceptable scale"1 }\end{array}$} & \multicolumn{3}{|c|}{$\begin{array}{l}\text { Rating in 9-point } \\
\text { Hedonic scale }\end{array}$} \\
\hline & \multicolumn{3}{|c|}{ Months of storage } & \multicolumn{3}{|c|}{ Months of storage } \\
\hline & Fresh & 8 & 12 & Fresh & 8 & 12 \\
\hline \multicolumn{7}{|l|}{ Number } \\
\hline 1 & 0.60 & 0.75 & 1.00 & 7.3 & 7.3 & 7.5 \\
\hline 2 & -.03 & .20 & .70 & 5.6 & 6.8 & 7.0 \\
\hline 3 & 1.00 & 1.00 & 1.05 & 7.6 & 7.5 & 7.7 \\
\hline $4^{2}$ & 1.20 & .80 & .90 & 7.8 & 7.1 & 7.2 \\
\hline $5^{2}$ & 1.00 & 1.00 & 1.00 & 7.7 & 7.6 & 7.6 \\
\hline 6 & 1.25 & .90 & 1.00 & 8.0 & 7.8 & 7.5 \\
\hline
\end{tabular}

1 Two scales were used for judging sample quality, a Kramer \& Dittman \pm 2 scale ranging from $+2=$ "very acceptable" to $-2=$ "unacceptable" and a 9 point scale ranging from $9=$ "like extremely" to $1=$ "dislike extremely".

Samples prepared from unpeeled fruit.

Acceptance tests were carried out locally and in continental United States to obtain further information on the acceptability of the papaya drink.

This papaya preparation was tasted by a group of 125 untrained tasters at Mayaguez, P.R., and 85 percent of them rated the drink between "acceptable" and "very acceptable". Evaluation results were also obtained from the Economic Development Administration, who distributed samples among those attending the convention of the U.S. Wholesale Grocers Association and Institutional Food Distributors in Miami, Florida. From the 500 opinions collected, 90 percent rated the sample as "acceptable".

Another test to obtain additional information on the consumer's reaction to the use of this papaya beverage was performed in cooperation with the Agricultural Service Administration of the Commonwealth Department of 
Agriculture. This test was conducted in Clinton, Iowa, by A. C. Nielsen and Co., Chicago, Ill. The results indicated a rather low degree of acceptance for this product in a typical American community with less than 10 percent of the tasters favoring it. The low acceptance level was attributed to the general unfamiliarity of the American consumer with papaya products.

\section{SUMMMARY}

A method was developed for the preparation of a good quality canned papaya beverage from the pulp of peeled and unpeeled fruit. Samples were prepared by passing a 1:1 mixture by weight of papaya pulp and sugar, through a stone mill and diluting with water to a 13-percent pulp content. Their flavor was enhanced by adding 0.4 percent of sliced ripe West Indian lime before its pasteurization. The preparations were adjusted to $15^{\circ} \mathrm{Brix}$, and the $\mathrm{pH}$ to 3.7 by adding citric or malic acid, then pasteurized at $190^{\circ} \mathrm{F}$. and canned.

The keeping quality of the beverage samples stored at $85^{\circ} \mathrm{F}$. was determined through sensory evaluation using a 9-point hedonic scale and a +2 , -2 rating scale and by chemical analyses at regular intervals. The samples prepared from peeled and unpeeled fruit showed excellent quality throughout the year of storage at $85^{\circ} \mathrm{F}$.

Three acceptance tests were conducted, one locally and two in the United States, to determine consumers' reaction to this type of papaya drink. Locally, almost 85 percent of the 125 opinions collected rated the product as "acceptable". In a test conducted in Miami, Fla., 90 percent of the 500 opinions collected appraised the drink as "acceptable." Samples also were evaluated to determine consumer acceptance of this papaya beverage at Clinton, Iowa, a typical American community unfamiliar with papaya products. Results indicated a rather low acceptance of the papaya drink.

\section{RESUMEN}

Se desarrolló un método para la preparación de un refresco de papaya de alta calidad usando la pulpa de la fruta pelada a mano y sin pelar. Se prepararon muestras de refrescos usando una mezcla de 1:1 por peso de pulpa de papaya y azúcar, previamente pasada por un molino de piedra, luego diluyendo la mezcla con agua hasta retener un contenido de 13 por ciento de pulpa. Antes de pasteurizar las muestras se les añadió un 0.4 por ciento de limón agrio del país en rebanadas para realzar el sabor del refresco. Las muestras fueron ajustadas a $15^{\circ}$ Brix y a un pH de 3.7 añadiendo ácido cítrico o málico y luego se pasteurizaron y enlataron.

La calidad de las muestras almacenadas a $85^{\circ} \mathrm{F}$. se determinó mediante pruebas sensoriales y análisis químicos. Se demostró que las muestras pre- 
paradas con la pulpa de frutas peladas a mano y frutas sin pelar conservaron su calidad durante un año de almacenamiento a $85^{\circ} \mathrm{F}$.

Se realizaron tres pruebas de aceptación para determinar la reacción de los consumidores hacia el refresco de papaya, una localmente y dos en los Estados Unidos. El 85 porciento de las 125 opiniones obtenidas en la prueba local catalogaron las muestras como "aceptables." En una prueba llevada a cabo en Miami, Fla., el 90 por ciento de las 500 opiniones obtenidas declararon que el refresco era "aceptable". El producto también se evaluó en Clinton, Iowa, comunidad americana típica, para determinar la aceptación que tendria entre personas que desconocieran este tipo de producto de la papaya. Los resultados indicaron una baja aceptación, atribuyéndose a la poca familiaridad de este tipo de consumidor americano con los productos de la papaya.

\section{LITERATURE CITED}

1. American Bottlers of Carbonated Beverages, Plan Operation Manual, Washington, D. C., 1940.

2. Cruess, W. V. and Irish, J. H., Fruit Beverages Investigation, Calif. Agr. Expt. Sta., Circ. 313, 1-64, 1928.

3. Cruess, W. V. and Irish, J. H., Unfermented Fruit Juices, Calif. Agr. Expt. Sta., Circ. 230, 1-32, 1928.

4. Jacobs, M. B., Carbonated-Non Alcoholic Beverages, The Chemistry and Technology of Food and Food Products, 2nd rev. ed., Vol. 3, 2,365-81, Interscience Publishers, Inc., New York, N. Y., 1951.

5. Kramer, A. and Ditman, L. P., A simplified variable taste panel method for detecting flavor changes in vegetables treated with pesticides, Food Technol. 10 (3): $155-59,1956$.

6. Official Methods of Analysis of the Association of Official Agricultural Chemists (A.O.A.C.), 10th ed., Washington, D. C., 1965.

7. Peryam, D. R. and Pilgrim, F. J., Hedonic scale method of measuring food preferences, Food Technol. 11 (9): $9-14,1957$. 